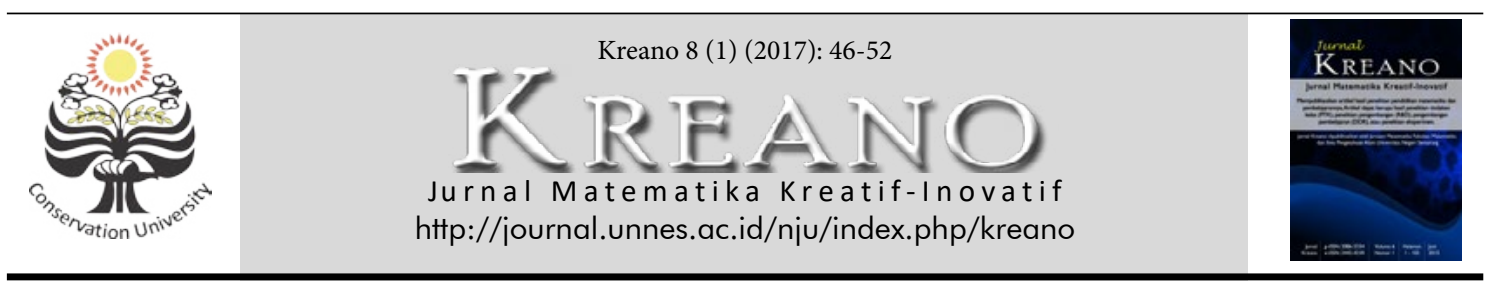

\title{
Penggunaan Mathmagic dalam Meningkatkan Motivasi Belajar Siswa
}

\author{
${ }^{1}$ Nenta Dumalia Siregar, ${ }^{2}$ Edy Surya \\ 1,2PPs Prodi Pendidikan Matematika UNIMED \\ Email: missnenta@gmail.com
}

DOI: http://dx.doi.org/10.15294/kreano.v8i2.7730

Received : November 2016; Accepted: January 2017; Published: June 2017

\begin{abstract}
Abstrak
Penelitian ini bertujuan untuk untuk mengetahui apakah dengan menggunakan metode mathmagic dapat meningkatkan motivasi belajar siswa kelas V SDN No.027688 Binjai T.A 2010/2011 yang barjumlah 35 orang siswa. Penelitian Tindakan Kelas ini dilaksanakan secara kolaborasi dengan guru kelas dalam dua siklus. Teknik pengumpulan data: observasi, tes, catatan lapangan dan dokumentasi. Teknik analisis data deskriptif. Hasil penelitian mengalami perubahan dilihat dari presentasi jumlah nilai dan rata-rata kelas. Sebelum dilakukan tindakan hanya 5 orang siswa $(1,25 \%)$ yang memperoleh hasil yang baik dengan nilai antara 2,80-3,39. Pada siklus I ada 2 orang siswa $(5 \%)$ memperoleh hasil yang sangat baik dengan nilai antara 3,40 - 4,00, dan 6 orang siswa (15\%) memperoleh hasil yang baik dengan nilai antara 2,80-3,39. Dengan kata lain meningkat menjadi $20 \%$. Pada siklus II ada 5 orang siswa $(12,5 \%)$ memperoleh hasil yang sangat baik dengan nilai antara 3,40-4,00, dan 27 orang siswa (67,5\%) mengalami perubahan yang memperoleh hasil yang baik dengan nilai antara 2,80-3,39. Berarti telah terjadi peningkatan menjadi $80 \%$.
\end{abstract}

\begin{abstract}
This research aims to to know whether using mathmagic method can improve the motivation of students in grade 5 at SDN No.027688 Binjai T.A 2010/2011 that barjumlah 35 students. This Class Action research carried out in collaboration with the class teacher in two cycles of. Data collection techniques: observation, tests, note field and documentation. Descriptive data analysis techniques. The results of research experience changes seen from the presentation number of values and the average class. Prior to the action only 5 students (1.25\%) who get good results with a value between $2,80-$ 3339. At cycle I no 2 the students (5\%) get very good results with a value between $3.40-4.00$, and 6 students (15\%) get good results with a value between $2.80-3,39$. In other words rose to $20 \%$. At cycle II is 5 students (12.5\%) get very good results with a value between $3,40-4,00$, and 27 students (67.5\%) experience changes that get good results with a value between 2,80-3,39. means there has been increased to $80 \%$.
\end{abstract}

Keywords: mathmagic, motivation learn, research class action.

\section{PENDAHULUAN}

Dalam keseluruhan proses penddikan disekolah, kegiatan belajar merupakan kegiatan yang paling pokok, ini berarti bahwa berhasil atau tidaknya pencapaian pendidikan banyak bergantung kepada bagaimana proses belajar yang dialami oleh siswa sebagai anak didik. Menurut Djamarah (2008) dalam bukunya psikologi belajar, mengemukakan bahwa "belajar adalah serangkaian kegiatan jiwa raga untuk memperoleh suatu perubahan tingkah laku sebagai hasil dari pengalaman induvidu dalam interaksi dengan lingkungannya yang menyangkut kognitif, afektif dan psikomotorik.

Merujuk pada berbagai pendapat para ahli matematika SD dalam mengembangkan motivasi dan kompetensi siswa, maka guru hendaknya dapat menyajikan pembelajaran yang efektif dan efisien, sesuai dengan kurikulum dan pola pikir siswa. Dalam mengajarkan matematika, guru harus memahami bahwa setiap kemampuan siswa berbeda-beda, serta tidak semua siswa menyenangi pelajaran matematika.

Menurut Heruman (2008) Belajar Ma- 
tematika berguna untuk mengembangkan kemampuan berkomunikasi dengan simbolsimbol serta ketajaman penalaran yang dapat memperjelas dan menyelesaikan permasalahan-permasalahan dalam kehidupan seharihari. Seseorang dikatakan belajar matematika, apabila seseorang tersebut melakukan kegiatan yang mengakibatkan perubahan tingkah laku yang berkaitan dengan matematika.

Motivasi merupakan faktor paling penting bagi pendidik dalam mencapai target yang bertujuan untuk meningkatkan pembelajaran. Ada lima hal yang mempengaruhi motivasi siswa yaitu : siswa itu sendiri, guru/ pendidik, isi materi pelajaran, metode atau proses pembelajaran, serta lingkungan (Williams et al, 2011).

Sedangkan menurut Levy (2008) motivasi siswa merupakan factor yang berpengaruh dan strategi yang dapat membantu mendorong serta menumbuhkan konsentrasi siswa dalam bidang akademik.

Metode mathmagic adalah salah satu model dalam pembelajaran matematika yang didirikan oleh Ir. Bekti Hermawan Handojo dan istrinya Ir. Srihari Ediati. Maksud dari metode mathmagic adalah bagaimana menciptakan penghitungan yang cepat pada operasi hitung matematika. Selain itu metode ini diharapkan mampu menciptakan anak yang dapat berhitung tanpa harus menggunakan alat bantu elektronik (kalkulator). Artinya anak diharapkan mampu menghitung KaBaTaKu (kali bagi tambah kurang) dengan daya nalarnya. Selain metode/metode mathmagic, pasangan suami istri ini mendirikan komunitas untuk siapa saja, dari berbagai propesi dan latar belakang pendidikan untuk selalu buka mata serta peduli, serta menghargai kejeniusan anak-anak termasuk dalam dunia pendidikan anak. Komunitas itu didirikan pada 1 Januari 2004 dengan nama Komunitas Buka Mata di kota Bogor (Handojo dan Ediati, 2005).

Sebagai contoh pengenalan konsep persegi dan persegi panjang. Dalam menyampaikan informasi mengenai persegi dan persegi panjang, terkadang guru langsung memberikan drill informasi tentang suatu bentuk bangun datar. Intinya pengenalan bangun datar ini hanya ditekankan pada pengenalan bentuk bangun serta analisi ciri bangun tersebut melalui pengamatan (Heruman, 2008).

Konsep luas persegi merupakan konsep perhitunganl uas bangun datar yang awal diajarkan pada siswa SD. Hal ini dikarenakan persegi digunakan sebagai satuan luas, misalnya meter persegi $\left(\mathrm{m}^{2}\right)$, atau juga centimeter persegi $\left(\mathrm{cm}^{2}\right)$. Selama ini siswa diberikan rumus menghitung luas persegi yaitu sisi yang satu dikali engan sisi yang lainnya (sisi x sisi). Meskipun cara ini tidak salah tetapi ada cara yang lebih memudahkan siswa dalam memperoleh rumus dan materi pelajaran yang lebih mudah dan menyenangkan (Heruman, 2008).

Dalam metode Mathmagic (MagicMath100, 2010), siswa diharapkan termotivasi dalam menyelesaikan permasalahan dalam bangun datar. Misalnya sebagai contoh mencari luas dan keliling persegi. Dalam mencari luas persegi misalnya menghitung persegi dengan contoh dibawah ini, maka dalam mencarinya dengan cara dilihat berapa satuan dari kiri ke kanan atau kanan ke kiri, lalu dilihat dari atas kebawah atau dari bawah ke atas. Lalu dikalikan sehingga dapatlah hasilnya. Maka akan sama jika kita menggunakan rumus sisi $x$ sisi. Dan dalam mencari keliling persegi adalah dengan menambahkan jumlah dari ke empat satuan sisi atau $4 \times$ sisi.

Metode Mathmagic adalah bagaimana menciptakan penghitungan yang cepat pada operasi hitung matematika. Selain itu metode ini diharapkan mampu menciptakan anak yang dapat berhitung tanpa harus menggunakan alat bantu elektronik (kalkulator).

Mathmagic adalah permainan di mana siswa diajak untuk bermain dengan angka dimana siswa memikirkan angka, menjumlahkan, mengalikan dan seterusnya (Koirala dan Goodwin, 2000)

Diharapkan dengan meningkatnya motivasi belajar matematika maka akan meningkat pula hasil belajar dan dapat meningkatkan hasil belajar siswa pula, mempunyai makna peningkatan prestasi belajar peserta didik dalam mata pelajaran matematika melalui metode mathmagic.

\section{METODE}

Penelitian tindakan kelas ini dilaksanakan di 
SD Negeri 027688 Binjai untuk mata pelajaran matematika. Penelitian ini dilaksanakan pada tahun ajaran 2010/2011 pada semester genap, yaitu bulan April sampai dengan Juni. Penentuan waktu penelitian mengacu pada kalender akademik sekolah, karena penelitian ini memerlukan dua siklus yang membutuhkan proses belajar mengajar yang efektif di kelas.

Subjek dari penelitian ini adalah seluruh siswa kelas V Sekolah SD Negeri 027688 Binjai Tahun Ajaran 2010/2011 yang barjumlah 40 orang siswa. Metode pengambilan sample yaitu dengan total sample. Jenis penelitian ini adalah Penelitian Tindakan Kelas (PTK). Sesuai dengan jenis penelitian ini, maka peneliti melakukan tahap-tahap penelitian yang berupa siklus. Proses dalam penelitian ini terdiri dari dua siklus, tiap siklus dilaksanakan sesuai dengan perubahan yang akan dicapai.

Desain penelitian yang dilaksanakan adalah desain yang digambarkan oleh Arikunto, dkk (2008) yang dilakukan secara skematis dengan dilalui dari tahapan yaitu 1) perencanaan, 2) pelaksanaan, 3)pengamatan dan 4) refleksi, sebagaimana tampak pada Gambar 1.

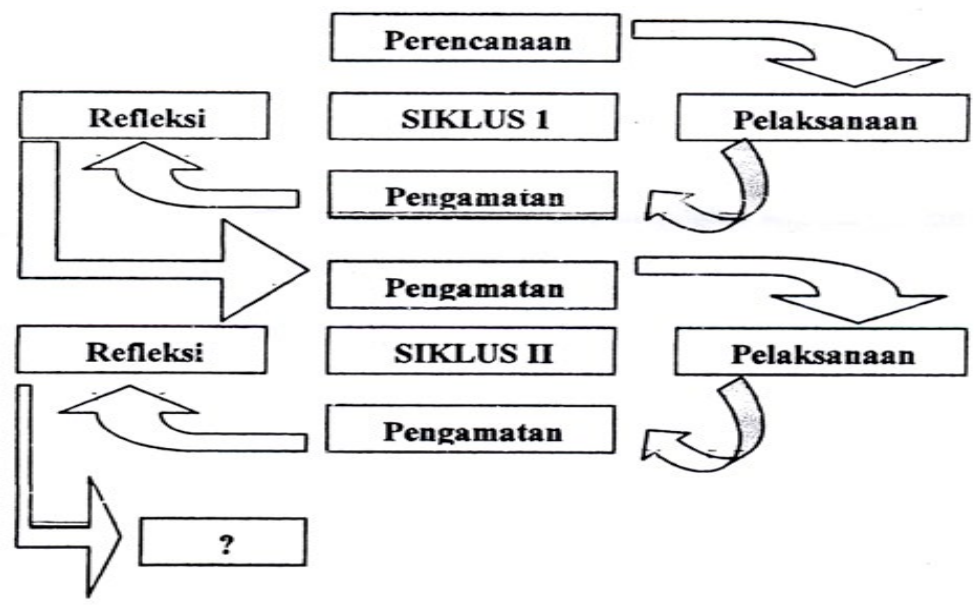

Gambar 1. Desain Penelitian menurut Arikunto, dkk (2008)

\section{Rancangan Siklus Pembelajaran}

\section{Tahap Perencanaan Tindakan}

Tahap ini dilakukan dengan langkah: (a) Melakukan Observasi awal untuk menentukan model dan format penerapan tindakan pada siklus I yang masing-masing siklus terdiri 2 kali pertemuan; (b) Melakukan analisis kurikulum untuk mengetahui kompetensi dasar yang akan disampaikan kepada siswa dalam pembelajaran; (c) Membuat lembar observasi guna mengamati proses pembelajaran lembar observer, dibuat untuk mengetahui proses pembelajaran yang sedang berlangsung; (d) Menyusun alat evaluasi untk mengetahui tingkat keberhasilan yang telah dicapai siswa pada siklus I.

\section{Tahap Pelaksanaan Tindakan}

Tahap ini dilakukan dengan: (a) peneliti menjelaskan tujuan pembelajaran yang sesuai dengan materi dalam 2 kali pertemuan; (b) peneliti memberikan soal yang berhubungan dengan materi pelajaran; (c) peneliti menjelaskan cara pengerjaan soal dengan memberikan contoh yang mudah dengan metode mathmagic; (d) Peneliti mengumpulkan dan mengecek jawaban siswa; dan (e) Peneliti melakukan evaluasi terhadap penguasaan siswa terhadap materi yang telah dipelajari.

\section{Tahap Observasi (Pengamatan)}

Hal-hal yang dapat diamati dalam tindakan kelas adalah : pengaruh tindakan, apakah terjadi kesesuaian antara rencana yang dibuat peneliti dengan implementasinya pada saat tindakan, situasi dan kendala dalam tindakan, dan persoalan-persoalan lain yang timbul.

\section{Tahap Refleksi}

Refleksi dilakukan dengan tujuan untuk me- 
lihat kesesuaian yang dicapai dengan keinginan dalam proses pembelajaran matematika. Dan hasil refleksi ini digunakan sebagai dasar untuk tahap perencanaan berikutnya.

\section{Tahap Evaluasi}

Tahap evaluasi dilakukan setelah selesai siklus. Berdasarkan hasil observasi dan hasil catatan lapangan, evaluasi dilakukan oleh peneliti. Kriteria evaluasi ditentukan $65 \%$ dari jumlah siswa mengalami peningkatan motivasi belajar setelah tindakan dilakukan selama siklus I terlaksana.

\section{HASIL PENELITIAN DAN PEMBA- HASAN}

\section{Hasil Penelitian}

Sebelum diterapkannya Metode Mathmagic, terlebih dahulu peneliti mengobservasi Kelas
V SD Negeri 027688 Binjai dengan tujuan untuk mengetahui Motivasi belajar siswa terhadap mata pelajaran Matematika.

Tabel 1. Konversi Nilai Angka Menjadi Huruf

\begin{tabular}{cccc}
\hline Konversi & Angka & Huruf & Keterangan \\
\hline $3,40-4,00$ & 4 & A & Sangat baik \\
$2,80-3,39$ & 3 & B & Baik \\
$2,60-2,79$ & 2 & C & Cukup \\
$0,00-2,59$ & 1 & D & Kurang \\
\hline
\end{tabular}

Berdasarkan lembar observasi yang menggunakan daftar checklist dari setiap indikator yang telah ditetapkan hampir rata-rata siswa memiliki motivasi belajar yang sangat rendah. Sebagian besar siswa tidak memiliki motivasi belajar pada mata pelajaran matematika sehingga siswa terlihat jenuh pada saat pembelajaran berlangsung, dapat dilihat pada table 2.

Pada Siklus I Guru melaksanakan tindakan yang terdiri dari: menentukan model

Tabel 2. Tabel observasi kondisi Awal Tingkat keberhasilan Siswa

\begin{tabular}{cccc}
\hline Tingkat keberhasilan & Arti & Jumlah (Orang) & Persentase Keberhasilan \\
\hline$>80 \%$ & Sangat baik & - & - \\
$60 \%-79 \%$ & Baik & 5 & $12,5 \%$ \\
$40 \%-59 \%$ & Cukup Baik & 7 & $17,5 \%$ \\
$20 \%-39 \%$ & Kurang & 28 & $70 \%$ \\
$<20 \%$ & Sangat Kurang & - & - \\
\hline
\end{tabular}

Tabel 3. Lembar Catatan Lapangan Aktivitas Guru

\begin{tabular}{|c|c|c|}
\hline Aspek & Kejadian & Uraian \\
\hline Penggunaan Rumus Mathmagic & Cukup & $\begin{array}{l}\text { Sebagian siswa belum tertarik untukmenggunakan Ru- } \\
\text { mus Mathmagic. }\end{array}$ \\
\hline Metode mengajar & Cukup & $\begin{array}{l}\text { Guru belum secara sepenuhnya menerapkan Metode } \\
\text { mathmagic }\end{array}$ \\
\hline Pengelolaan kelas & Cukup & $\begin{array}{l}\text { Intensitas guru mengawasi kerja setiap kerja siswa harus } \\
\text { ditingkatkan lagi }\end{array}$ \\
\hline Media dan alat pengajaran & Cukup & $\begin{array}{l}\text { Guru sudah menggunakan media saat mengajar, namun } \\
\text { gambarnya masih terlalu kecil }\end{array}$ \\
\hline Penampilan dan gaya mengajar & Baik & Guru menguasai materi yang diajarkan \\
\hline Kegiatan pembelajaran & Baik & Sesuai dengan RPP \\
\hline
\end{tabular}

Tabel 4. Lembar Catatan Lapangan Aktivitas Siswa

\begin{tabular}{lll}
\hline \multicolumn{1}{c}{ Aspek } & Kejadian & \multicolumn{1}{c}{ Uraian } \\
\hline $\begin{array}{l}\text { Aktivitas belajar } \\
\begin{array}{l}\text { Semangat dalam mengi- } \\
\text { kuti pembelajaran }\end{array}\end{array}$ & Baik & Siswa terlihat senang, cukup aktif dikelompoknya \\
$\begin{array}{l}\text { Interaksi antar siswa } \\
\begin{array}{l}\text { Interaksi siswa dengan } \\
\text { guru }\end{array}\end{array}$ & Cukup & $\begin{array}{l}\text { Siswa terlihat bersemangat mengikuti pembelajaran } \\
\text { Jika tidak diawasi, masih ada siswa yang tidak bekerja sama } \\
\text { dengan kelompoknya } \\
\text { Siswa memperhatikan petunjuk dan arahan guru dalam proses } \\
\text { belajar mengajar }\end{array}$ \\
\hline
\end{tabular}


dan format penerapan PTK, Membuat RPP, Menyusun daftar checklist dan daftar catatan lapangan. Proses ini terbagi menjadi dua kali pertemuan, masing-masing pertemuan berlangsung selama $2 \times 35$ menit. Selain itu peneliti dalam pelaksanaan pembelajaran juga menggunakan bahasa positif (memberi penguatan) kepada siswa agar siswa lebih merasa dihargai atas usahanya dalam mengerjakan sesuatu dan pemberian bahasa positif ini diterapkan untuk dapat meningkatkan motivasi belajar siswa.

Berdasarkan hasil observasi tersebut dapat disimpulkan bahwa beberapa siswa masih malas menerapkan rumus-rumus mathmagic yang diberikan guru, penggunaan media pembelajaran guru kurang menarik perhatian siswa karena gambarnya masih terlalu kecildan peneliti belum mampu mengelola keadaan kelas secara maksimal agar suasana kelas dapat lebih tertib.

Pada Siklus II, guru tetap menerapkan bimbingan dengan menggunakan Metode Mathmagic. Hal ini bertujuan agar siswa lebih semangat lagi untuk mengikuti pelajaran dan kegiatan belajar bisa lebih kondusif lagi karena dari hasil refleksi dan evaluasi pada siklus I, dapat disimpulkan bahwa kegiatan pembelajaran belum benar-benar kondusif.

Pada tahap ini kegiatan yang dilakukan peneliti adalah sama dengan siklus I hal ini dikarenakan berdasarkan hasil observasi yang telah dilakukan banyak siswa yang senang dalam mengikuti kegiatan pembelajaran yang diterapkan oleh peneliti. Peneliti bersama guru kelas dan teman sejawat melakukan observasi dan lembar catatan lapangan kepada siswa terhadap pelaksanaan tindakan yang menggunakan Metode Mathmagic. Hasil yang didapatkan selama observasi dilaksanakan dapat dilihat pada 6 dan 7 .

Dari tabel 6 dan 7 diatas dapat dilihat bahwa penggunaan Metode Mathmagic telah efektif untuk meningkatkan motivasi belajar

Tabel 5. Tabel observasi Tingkat keberhasilan Siswa Pada Siklus I

\begin{tabular}{cccc}
\hline Tingkat keberhasilan & Arti & Jumlah (Orang) & Persentase Keberhasilan \\
\hline$>80 \%$ & Sangat baik & 2 & $5 \%$ \\
$60 \%-79 \%$ & Baik & 6 & $15 \%$ \\
$40 \%-59 \%$ & Cukup Baik & 14 & $35 \%$ \\
$20 \%-39 \%$ & Kurang & 18 & $45 \%$ \\
$<20 \%$ & Sangat Kurang & - & - \\
\hline
\end{tabular}

Tabel 6. Lembar Catatan Lapangan Untuk Aktivitas Guru

\begin{tabular}{|c|c|c|}
\hline Aspek & Kejadian & Uraian \\
\hline Penggunaan sumber belajar & Efektif & $\begin{array}{l}\text { Penggunaan sumber belajar membuat siswa termoti- } \\
\text { vasi belajarnya }\end{array}$ \\
\hline Metode mengajar & Bervariasi & $\begin{array}{l}\text { Guru telah menggunakan metode mathmagic sesuai } \\
\text { dengan langkah-langkahnya. }\end{array}$ \\
\hline Pengelolaan kelas & Baik & $\begin{array}{l}\text { Guru dapat mengelola keadaan kelas dengan baik, dari } \\
\text { mulai penyusunan kursi hingga penertiban kelas }\end{array}$ \\
\hline Media dan alat pengajaran & Sangat baik & Media yang digunakan guru relevan dan menarik \\
\hline Penampilan dan gaya mengajar & Sangat Baik & Guru menguasai materi yang diajarkan \\
\hline Kegiatan pembelajaran & Baik & Sesuai dengan RPP \\
\hline
\end{tabular}

Tabel 7. Lembar Catatan Lapangan Untuk Aktivitas Siswa

\begin{tabular}{|c|c|c|}
\hline Aspek & Kejadian & Uraian \\
\hline Aktivitas belajar & Sangat baik & Siswa mau bertanya dan menjawab pertanyaan dari guru \\
\hline $\begin{array}{l}\text { Semangat dalam mengikuti } \\
\text { pembelajaran }\end{array}$ & Baik & Siswa terlihat bersemangat mengikuti pembelajaran \\
\hline Interaksi antar siswa & Baik & $\begin{array}{l}\text { Siswa saling bekerja sama dengan temannya menyele- } \\
\text { saikan tugas yang diberikan guru }\end{array}$ \\
\hline Interaksi siswa dengan guru & Baik & Siswa mau bertanya dan menjawab pertanyaan guru \\
\hline
\end{tabular}


siswa, hal tersebut dapat dilihat dari semangat belajar yang ditunjukkan siswa dalam proses pembelajaran, siswa juga telah memiliki interaksi yang baik dengan siswa lainnya dalam menyeleaikan tugas yang diberikan oleh guru, dan saat guru mengajukan pertanyaan siswa antusias menjawab serta saat ada hal atau materi yang belum dipahami siswa mau menanyakannya kepada guru, kemampuan guru dalam mengelola kelas juga baik sehingga keadaan kelas saat proses pembelajaran dan diskusi berlangsung dengan tertib, sehingga dapat disimpulkan bahwasannya kegiatan pembelajaran dengan menggunakan Metode Mathmagic yang dilakukan oleh guru sudah menampakkan perubahan motivasi belajar siswa.

Tabel 8. Tabel observasi Tingkat keberhasilan Siswa Pada Siklus II

\begin{tabular}{cccc}
\hline $\begin{array}{c}\text { Tingkat ke- } \\
\text { berhasilan }\end{array}$ & Arti & $\begin{array}{c}\text { Jumlah } \\
\text { (Orang) }\end{array}$ & $\begin{array}{c}\text { Persentase } \\
\text { Keberhasilan }\end{array}$ \\
\hline$>80 \%$ & Sangat baik & 5 & $12,5 \%$ \\
$60 \%-79 \%$ & Baik & 27 & $67,5 \%$ \\
$40 \%-59 \%$ & Cukup Baik & 8 & $20 \%$ \\
$20 \%-39 \%$ & Kurang & - & - \\
$<20 \%$ & Sangat & - & - \\
& Kurang & & \\
\hline
\end{tabular}

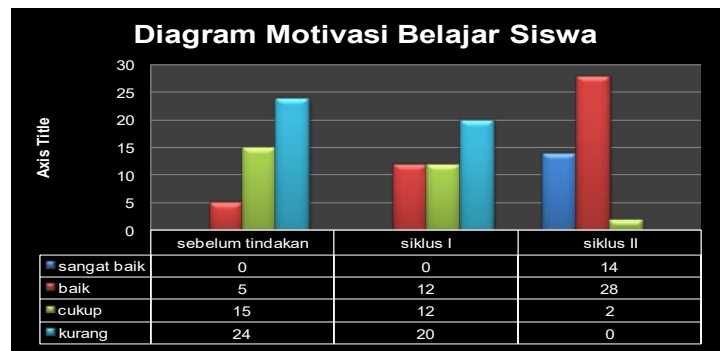

Gambar 2. Diagram Motivasi Belajar Siswa

Berdasarkan pelaksanaan kegiatan pada siklus I dan siklus II yang telah dilakukan oleh peneliti, maka perubahan yang terjadi pada motivasi belajar siswa dapat dilihat pada diagram dibawah ini.

Dari hasil penelitian dapat dilihat bahwa motivasi belajar siswa pada siklus I menunjukkan bahwa ada 2 siswa (5\%) yang memperoleh hasil yang sangat baik dengan nilai antara 3,40-4,00, 6 siswa (15\%) memperoleh hasil yang baik dengan nilai antara 2,80-3,39, ada 14 siswa (35\%) memperoleh hasil yang cukup dengan nilai antara 2,60-2,79, ada 18 siswa
(45\%) yang memperoleh hasil yang cukup dengan nilai antara 0,00-2,60.

Kemudian, setelah diadakan tindakan pada saat proses pembelajaran pada hasil tindalan siklus II yaitu sebanyak 5 siswa $(12,5 \%)$ memperoleh hasil yang sangat baik dengan nilai antara 3,40-4,00, ada 27 siswa (67,5\%) yang memperoleh hasil yang baik dengan nilai antara 2,80-3,39, ada 8 siswa (20\%) memperoleh hasil yang cukup dengan nilai antara $0,00-2,59$.

Dari data diatas dapat dilihat bahwa semua siswa mengalami perubahan motivasi belajar dengan tekun menghadap tugas, ulet menghadapi kesulitan, menunjukkan minat terhadap bermacam-macam masalah, lebih senang bekerja mandiri, tidak mudah jenuh dalam proses pembelajaran, dapat mempertahankan pendapatnya, dan senang dalam mencari dan memecahkan masalah.

\section{Pembahasan}

Berdasarkan hasil penelitian dapat dilihat bahwa ada perubahan motivasi belajar siswa yang terjadi setelah dilakukannya pembelajaran dengan metode mathmagic.

Selain itu,penelitian ini juga didukung oleh penelitian yang dilakukan oleh yang menyatakan bahwa melalui metode mathmagic dapat meningkatan prestasi belajar peserta didik dalam mata pelajaran matematika. Penelitian lain yang dilakukan oleh Irawan dan Catharina (2016) juga menyatakan bahwa mathmagic dapat menjadi salah satu metode yang efektif dan efisien serta sebagai solusi untuk memberikan kemudahan siswa dalam mempelajari matematika.

Mathmagic adalah permainan di mana siswa diajak untuk bermain dengan angka dimana siswa memikirkan angka, menjumlahkan, mengalikan dan seterusnya (Koirala dan Goodwin, 2000)

Penggunaan teori Mathmagic ini sesuai dengan teori belajar menurut ilmu Gestalt (Mathmagic, 2010). Teori ini berpandangan bahwa dalam kegiatan belajar bermula pada suatu pengamatan. Pengamatan itu penting dilakukan secara menyeluruh.

Goos (2004) menjelaskan bahwa pengetahuan akan mudah didapat melalui interaksi sosial dan kemudian dari interaksi sosial terse- 
but akan diperoleh pengetahuan bagi individu yang terlibat dalam kegiatan sosial tersebut.

\section{PENUTUP}

\section{Simpulan}

Berdasarkan hasil penelitian dan pembahasan maka dapat disimpulkan bahwa motivasi belajar siswa mengalami peningkatan setelah diberikan perlakuan dengan menerapkan Metode Mathmagic pada saat kegiatan pembelajaran, hal ini berarti metode Mathmagic efektif digunakan pada pelajaran Matematika khususya dalam pokok bahasan Bangun Datar.

\section{Saran}

Beberapa hal yang disarankan dalam tulisan ini adalah sebagai berikut: Agar guru meningkatkan motivasi belajar siswa dengan menggunakan Metode Mathmagic. Disarankan agar guru menggunakan Metode Mathmagic dalam mengajar baik pada pelajaran Matematika pokok bahasan Bangun Datar maupun mencobanya pada pelajaran lain. Demikian pula agar kepala sekolah mengembangkan atau melatih para guru agar terampil meng- gunakan berbagai macam Metode mengajar terutama Metode Mathmagic.

\section{DAFTAR PUSTAKA}

Arikunto, S. (2008). Prosedur Penelitian Suatu Pendekatan Praktek. Jakarta: Rineka Cipta.

Irawan, A., \& Febriyanti, C. (2016). Efektifitas Mathmagic dalam Peningkatan Hasil Belajar Matematika. Formatif: Jurnal Ilmiah Pendidikan MIPA, 6(1).

Djamarah, S.B. (2008) Strategi Belajar Mengajar. Edisi Revisi, cet. Ke 2. Jakarta: Rineka Cipta.

Goos, M. (2004). Learning mathematics in a classroom community of inquiry. Journal for research in mathematics education, 35(4), 258-291.

Handojo, B.H. dan Ediati, S. (2005) Math Magic. Jakarta: PT. Kawan Pustaka.

Heruman. (2008) Model pembelajaran Matematika Di Sekolah Dasar. Bandung: Rosda.

Koirala, H. P., \& Goodwin, P. M. (2000). Teaching algebra in the middle grades using math magic. Mathematics Teaching in the Middle School, 5(9), 562566.

Levy, S., \& Campbell, H. (2008). Student Motivation: Premise, Effective Practice and Policy. Australian Journal of Teacher Education, 33(5), n5.

Tim MagicMath. (2010). Seri matematika mudah MagicMath10o, (Bidang datar, bangun Ruang, dan Konversi satuan). Jakarta: Elex Media Komputindo, Kompas Gramedia.

Williams, K. C., \& Williams, C. C. (2011). Five key ingredients for improving student motivation. Research in Higher Education Journal, 12, 1. 